\title{
A rare cause of genital ulcer
}

Rita da Fonseca Lourenço, ${ }^{1}$ Ana Isabel Gouveia, ${ }^{2}$ Joana Azinheira Oliveira, ${ }^{3}$ José Gonçalo Marques ${ }^{4}$

${ }^{1}$ Hospital do Divino Espirito Santo de Ponta Delgada, Ponta Delgada, Açores,

Portugal

${ }^{2}$ Department of Dermatology, Hospital de Santa Maria, Lisbon, Portugal

${ }^{3}$ Centro Hospitalar Lisboa Norte EPE, Lisboa, Portugal

${ }^{4}$ Pediatric Infectious Diseases, Pediatric Department, Hospital de Santa Maria, Lisbon, Portugal

\section{Correspondence to}

Dr Rita da Fonseca Lourenço, ritadafonsecalourenco@gmail. com

Accepted 15 July 2015

\section{DESCRIPTION}

Lipschütz ulcer is a rare condition characterised by the rapid onset of vulvar painful necrotic ulcerations. It typically occurs in sexually inactive girls and may be preceded by influenza-like symptoms. The aetiology is unknown, although recent reports

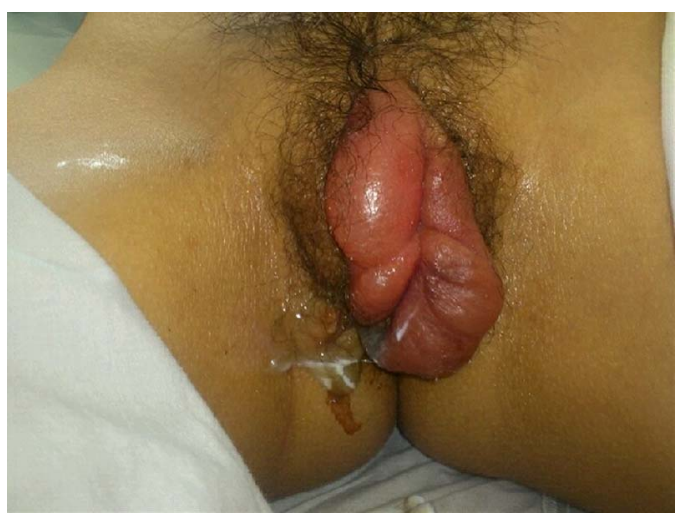

Figure 1 Initial presentation with vulvar oedema.

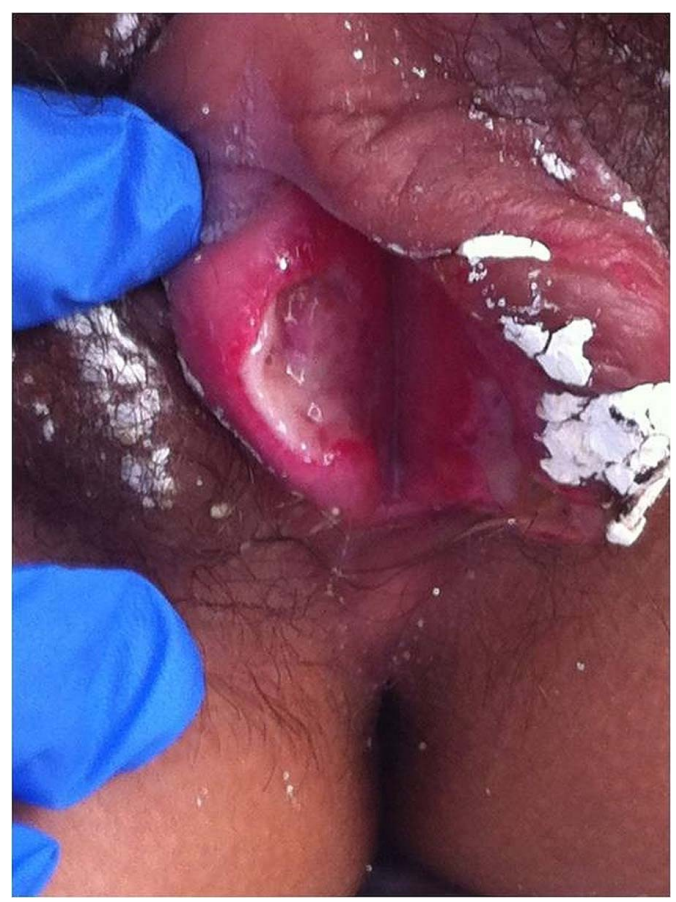

Figure 2 Acute ulceration of the labia minora with a symmetrical appearance ('kissing pattern'). have associated it with acute Epstein-Barr virus infection. The diagnosis is clinical, after ruling out other causes of genital ulcerations such as sexually transmitted and autoimmune diseases and trauma. ${ }^{1-3}$ We report a case of a healthy 13-year-old girl who developed flu-like symptoms and painful vulvar oedema (figure 1) followed by the appearance of labia minora ulcers (figure 2), without other mucosal or skin lesions. Complementary examinations were negative for microbial or autoimmune aetiology; there was no history of trauma, sexual activity or abuse. Herpes simplex virus testing (HSV PCR skin swab and HSV-type specific serology), Epstein-Barr virus, syphilis and HIV serology were negative. Symptomatic treatment was performed with topical and systemic analgaesia. Lesions healed in 6 weeks with no sequelae or recurrences. This case represents a rare differential diagnosis of genital ulceration, with an exuberant clinical presentation, often requiring hospitalisation for pain control and yet with good prognosis.

\section{Learning points}

- The aetiopathogenesis of Lipschütz ulcer is still unknown, but has been associated with infectious diseases such as Epstein-Barr virus infection.

- Diagnosis is mainly clinical, after exclusion of other causes of vulvar ulcers.

- The treatment is symptomatic and healing occurs spontaneously.

Competing interests None declared.

Patient consent Obtained.

Provenance and peer review Not commissioned; externally pee reviewed.

\section{REFERENCES}

1 Delgado-García S, Palacios-Marqués A, Martínez-Escoriza JC, et al. Acute genital ulcers. BMJ Case Rep 2014;2014:-m.

2 Brinca A, Canelas MM, Carvalho MJ, et al. Lipschütz ulcer (ulcus vulvae acutum): a rare cause of genital lesion. An Bras Dermatol 2012;87:622-4.

3 Levy Bencheton A, Agostini A, Mortier I, et al. [Acute vulvar ulcer of Lipschütz: a misdiagnosis entity]. Gynecol Obstet Fertil 2011;39: e58-60. 
Copyright 2015 BMJ Publishing Group. All rights reserved. For permission to reuse any of this content visit http://group.bmj.com/group/rights-licensing/permissions.

BMJ Case Report Fellows may re-use this article for personal use and teaching without any further permission.

Become a Fellow of BMJ Case Reports today and you can:

- Submit as many cases as you like

- Enjoy fast sympathetic peer review and rapid publication of accepted articles

- Access all the published articles

- Re-use any of the published material for personal use and teaching without further permission

For information on Institutional Fellowships contact consortiasales@bmjgroup.com

Visit casereports.bmj.com for more articles like this and to become a Fellow 